\title{
Postmodern Reflections in the Work "Ruhm" by Daniel Kehlmann
}

\author{
Muge Arslan \\ Research Assistant. Selcuk University, German Literature Department, Konya, Turkey \\ E-mail: mugearslan@selcuk.edu.tr, Tel: 00905057400800 \\ Ulfet Dag \\ Research Assistant. Selcuk University, Comparative Literature Department, Konya, Turkey \\ E-mail: ulfet_dag@hotmail.com, Tel: 00905514068548
}

\section{Doi:10.5901/ajis.2013.v2n8p326}

\begin{abstract}
Postmodernism, which making a principle ambiguousness and uncertainty instead of rationality and functionality of modernism and skeptical any statement, has brought many innovations to literature.Postmodernism is trying to utter the elements which cannot be displayed when applied to literature, it benefits from intertextuality, so it doesn't ignore before, makes references and also reminiscent of the Works. However, this understanding eliminates all the existent spaces, times and concepts of personality and revealed new spaces, times and self-described personalities determined by each author. On that score, postmodernism, which nourishes from subjectivity, isn't clearly identified. This concept defined as postmodernism, which approaches skeptic to be defined, is uncertain, formed as uncertainty and clear to all kinds of variability. So in this study its reflections in literature will be discussed. Consequently, a review will be on what one need to have to examine postmodern literary Works, with examples of this work (Fame).
\end{abstract}

Keywords: Postmodernism, Daniel Kehlmann, Ruhm (Fame), metafiction, intertextuality.

\section{Introduction}

Postmodernism is not a fact that can easily be described both as a concept and also in terms of its reflection to literature. A concept and way of thinking reflection to literature, the description of postmodernism is still being tried to be defined. Furthermore, obscurity of the word and hardness in definition has retained this movement that shows itself in literature from de facto descriptions. One of the most significant reasons of this is that postmodernism includes eclectical structure; particularly it includes many things from each period, each author, and each literal work within literary content. Rather than trying to describe this development the principle of which is to include invisible elements, obscurity and indefinableness with words, a criteria catalogue can be established by using literal works that can be described as postmodern. This method can be more de facto as the beginning point will be samplings and thus this can determine the place of the work in hand among the other works that are also described as postmodern. In this study, criteria catalogue will be established rather than describing the concept with aforementioned purposes and compliance of work by Daniel Kehlmann called "Fame" to the literal form named postmodernism will be examined as per these criteria. The original name of the Work is "Ruhm" but its english translation "Fame" will be used in the paper.

There is a group that claims postmodernism as a culture and idea movement that follows modernism in principle conceptually (see: http://www.frustfrei-lernen.de). Besides from this, another group considers postmodernism as a phase that exceeds modernism, that interrogates recognized certainties and conclusiveness of modern science and as a reflection of what people are curious about incredible and unthinkable issues (Türk, 2012: 16). To Ihab Hassan "The word postmodernism sounds not only awkward uncouth; it evokes what it wishes to surpass or suppress, modernism itself" (Hassan, 1993: 148). Postmodern literature has changed perceive of Unity (Einheit), Identity (Identität), and Meaning (Sinn) concepts in Modern literature. On the contrary to the modernism that does not accept the deficiency of these, it assumes the lack of unity, identity and meaning as a profit and even accepts this deficiency as it paves the way for pluralism (Just as Lyotard and Welsch asserts) (see: Harbers, 2000:9).

In our study, work will be studied under the titles of kitsch, identity, eclectical structure and metafiction. A general evaluation will be carried out basing on all these elements within the frame of plurality. 


\title{
2. Kitsch
}

The origin of the word "Kitsch" (Werkkitschen) is German and this word is generally described as disprize, desublimation, commercialization, duplication and aesthetic improperness. All works excluding aesthetic concerns (aesthetic guided) were evaluated as kitsch in modernism and these kinds of works were not accepted as significant in modern literature. This style that was not accepted by modernism. Postmodern literature and kitsch is tried to be included in art together with pop art. Thus kitsch is included in art as against modernism (see: Aslışen, 2006: 6). Kitsch is fed with some instruments such as eclecticism, intertextuality, metafiction, plurality, a lasting place for itself. Specified as "Making art entertaining" (op.cit.: 3) kitsch had negative meaning at first, but nowadays it has a positive uncertainty and irony in literature. As the mass media gains more importance day by day meaning in some way thanks to postmodern literature (see: Gelfert, 2010:164). "It's main purpose is to convey the message to the addressee in a direct way and in a way that easily be understood and do not have any aesthetic concern for this purpose." (op.cit.: XII). Kitsch is smartened with paradoxical items and includes heavy emotional themes and thus easily let people wander around realms of imaginary. "Fame" by Daniel Kehlmann contains kitschy elements and can be considered as it serves to postmodern literature.

The most remarkable kitsch elements in novel can be seen with dilemmas in stories. The protagonists are between two women and while praising one, and insist on desiring for other and also can give up none of them. This situation is mentioned in the first and fourth stories but the most dominant one is seen in the eight one. Depression arising from this case and the completion of the crisis are left for reader. The protagonist, stock his wife, Hannah, and his beloved, Luzia, continues his life with several lies and expresses the ease of deceiving and being deceived because of technology:

\begin{abstract}
"How strange that technology has brought us into a world where there are no fixed places anymore. You speak out of nowhere, you can be anywhere, and because nothing can be checked, anything you chose to imagine is, at bottom, true. If no one can prove me where I am, if I myself am not absolutly certain, where is the court that can adjudicate these things?" (Fame: 100).
\end{abstract}

"How did it happen in old days? How did you lie and deceive, how did you have affairs, how did you get away and manipulate and orginize your secret activities without the help of ultra-sophisticated technology?" (op.cit.: 101).

One of the protagonists who have dilemmas is Ebling. Despite his unreliable attitude against technology as a technician, in the end, he cannot refuse the bringing of the era and bought himself a cell phone. And then the moments that he does not want to be far away from his mobile phone explicitly show his addiction to it increasing day by day: "Not so long ago you didn't want anything to do with one (phone), and now you don't budge an inch without it. Just relaxnothing can be that urgent" (op.cit:: 16).

Furthermore, kitsch elements can also be observed in the second story, "In Danger". A successful author Leo Richter is always being asked about the origin of his ideas. Leo answers this question in an ironic way and says "bathtube". Being expected to give more serious, didactic and guiding answer on the origin of his ideas as it is significant, Leo surprises everyone with this way of reply:

"Why do they always ask that?" Leo whispered in the car. "Where do I get my ideas from. What kind of a question is that, what am I supposed to say?"

"Well, what do you tell them?"

"Bathtub."

"Excuseme?"

"I say I gey all my ideas in the bathtub. That does it for them. They're happy" (op.cit.:24).

There is nothing in Kitsch that is impossible. Postmodern literature reunites the things that are accepted as impossible with reader by turning these into possible things. Rosalie wants Leo Richter, who is her creator, to heal her disease. At first Leo expresses that this is impossible but then heals her and even make her younger. (see: $33,34,45)$ Being a novel hero, Lara Gaspard emerges in the last story, "In Danger" as a real novel hero. She meets and converses with Elizabeth:

"Excuse me." A handshake, both soft and strong. "A pleasure to meet you. I'm Lara Gaspard."

"You're..." Eisabeth rubbed her forehead. "Weren't you....in America?"

"A long story. Very complicated. My whole life is one long story of complications" (op.cit.: 116).

Some sources indicate that Miguel Auristos Blancos hero in the sixth story, is a copy of Brazilian author Paulo 
Coelho and this can be considered as kitsch. The reason for this is the similarity between Miguel's guiding books and ideas on personal development and Paulo Coelho's ideas (see: http://www.berlinerliteraturkritik.de). In this story, ideas on Miguel or the style of the author is completely compatible with kitsch. While kitsch is evaluated as copy of the originals, the similarities between Miguel and Paulo are examples for this situation:

"As always when he came back from the toilet, he felt both comforted and prey to a vague melancholy. (...) he trotted on a groaning, Rolling treadmill about which he had once written a little book on the affirmation of uniformity, the changes within continuity, and the gentle swaying of the spirit as it moves between exhaustion and concentratio" (Fame: 71).

In addition to this, it is also remarkable that the life style of the hero in the eighth story and Coelho have many similarities. Coelho's mother continuously tells that he should choose engineering as an occupation just as his father, rather than choosing authorship, so does the father of the hero of the story by expressing that reading books is not an occupation and in the end the hero studies in electrical engineering and specializes in mobile communication (see. op.cit.: 94).

The works that can be described as Kitsch have universal theme and the scenes take place in unusual ambiances. This novel also refers to universal issues by using technology. Heroes Leo Richter, Elizabeth, Maria Rubinstein, Madame Riedergott try to manage the events that they face with in far away and exotic places (Central Asia, Central America, Africa).

\section{Identity}

Phenomenon of identity in postmodern literature emerges in comply with plurality, obscurity, metafiction technique and eclectic structure of postmodernism. Characters are self-alienated, lean questioning themselves and try to know themselves by getting even within the plot. The identity crisis of the characters in aforementioned work by Daniel Kehlmann is explicit. All characters in stories question their existence, identity and personality:

"To distract herself, she looks in the goldframed mirror that's hanging on the wall. Is that really us? These little hats and crocodile handbags and eccentrically made-up faces, these fussy gestures and ridiculous clothes? What happened?" (op.cit.: 35) (also see the pages 93,94,102)

Identity that covers obscurity propels readers to differentiate the real entities and fictional entities. There are not any characteristic features of heroes and therefore there are not any specifications that reflect their identity. Who is who, where is where, what is real, what is fictional is not known, everything is messed up, in obscurity and interlocked. Identity that directs us on personifying people, has acquired a new dimension in this work in associate with postmodern literature and has abolished the possibility of personifying characters:

"Every one of us was once promised the kingdom of heaven and none of us wants to acknowledge that we're part of these people we never wanted anything to do with, have been for years, that nothing about $s$ is exceptional, and that it's precisely the sense that we're different that makes us so banal" (op.cit.: 98).

Heroes that question their existence, their place in the society that is to say their reflections disappear. Their being alone and away from their friends and families cause their curiosity on whether they are being realized or not and thus lead a new question for them. In this story, the reality that they are not recognized results in a new identity crisis as they are sure that they will be recognized. In the mean time, their existence becomes alienated to themselves:

"Was it possible that the others handn't (hadn't) noticed she was missing, or that they'd accepted some threadbare explenation to avoid any delay in their own departure? Something told her this was perfectly possible" (op.cit.: 62,63).

(also see: 64, 93,94)

Characters impersonated into different characteristics. Changes in identity which are at first entertaining causes dilemma on people and result in forgetting their identities that is who they are. Ebling, pretends as Ralf, starts to play within the play and Ralf Tanner who strips from his identity by creating a new identity for himself with his new name, Mathias Wagner, also loses his Ralph identity in the end: "He would like to have known more about Ralf's life; after all, it was now, to small extent, his life too" (op.cit.: 13; also see: 48, 49, 50).

One of the other attention grabbing points is that Ralf's new identity is actually a character that tries to have Ralf's 
identity. That means Ralf is trying to have a new identity getting rid of his own, but his preference is a character that pretends to be Ralf. This case that is stripping from his own identity refers freedom for him. As we can observe the same situation in other characters -characters' being alienated from their identities eventually- reminds us the need or wish in having someone else's identities by leaving ours when faced with some situations. The reason for that is sometimes it is hard to be ourselves. Therefore Ralf finally realizes that nobody resemble to its own (self) :

"No, he thought on the streetcar on the way to Matthias Wagner's place. Of course it didn't prove anything of the sort, it merely showed that self-examination disturbs the personality, deflects the will, and saps the mind; it proved that no one, seen celarly from the outside, resembles themselves at all" (op.cit.: 51). (also see: 55,92)

People in postmodern literature are engaged with their own interests and worries that they cannot realize the things going on. This is the starting point of the disidentification of characters:

"(...)and yet again she was forced to realize that people were bound up in their own preoccupations and worries, and registered so little of what was actually going on in front of them" (op.cit.:29).

"Mirror" that helps people, lost among disidentification, facing-off the realities is found as a strong metaphor. Motive of mirror ends up dreams and fictions and leads characters face with realities. Moreover, it emerges how the characters are alienated to themselves and their identities. "Ralf paused for awhile in front of the mirror on the wall, and watched his face become less and less recognizable by the second" (op. cit.:52). (also see: $35,45,48,53$ )

Besides metaphor of mirror, there is also motive of "glass" and it has the same reference with mirror that is reflection of people: "He tried to see himself in the glass, but it didn't work, any more thn it did in shop Windows, there seemed to be no more reflecting surfaces to be found anywhere" (op.cit.: 53 ). (also see: 55,56 )

Existences of heroes are not determined with sharp and net borders. A hero that is created can disappear all of a sudden and without any reason. This can be associated with the dialectics of postmodern literature:

"For like Rosalie I cannot imagine that I'm a nothing if I'm not being observed by somebody else, and that my only halfreal existence ends the moment that somebody takes his eyes of me-just as, now that I'm finally ending this story, Rosalie ceases to exist. From one moment to the next. Without any death throes, pain, or transition" (op.cit.: 46).

Change of identity is shown in fifth story in a different way. In this story Maria Rubinstein attends a meeting abroad on behalf of Leo, as Leo cannot attend this meeting. So Maria does everything and lives instead of Leo: "I'm here instead of Leo Richter. They sent me his ticket. I'm replacing him" (op.cit.: 58).

As in seventh story another dimension of identity change is observed. Being addicted to internet our hero, Mollwitz, enters into forum sites by leaving his own identity apart and having pseudonym and information. This is a transformation for him that means transferring himself into another thing:

"Leo used stuff he saw? Guys he met? Events that happened? Yes, he could even us me. Nothing against it! Appearing in a story - really no different from being in a chat room. Transformation! Transport yourself into some other place. In a story l'd be someone else, but also me. In the same world as Lara" (op.cit.: 85).

As change of identities provides leaving characters' own identities, looking from external perspective and evaluation and questioning their identities, it gains a new point of vision:

"(...)And suddenly was seeing myself from the outside as if it wasn't me; result more stuttering, and result more stuttering still. (...)l saw myself standing there looking at myself" (op.cit.: 87,88).

Heroes' changing their identities and emerging with more than one identities in Postmodern literature can be in relation with the principle of plurality. This can be interpreted as wish of being sophisticated. In parallel to the principle of plurality, it can be indicated that a second personality is available in each character:

"(...)Because a man wishes to be many things. In the literal sense of the world. He wishes to be multiple. Diverse. He'd like to have several lives. But only superficially, not deep down" (p.108,109). (also see: 100, 105,106)

After identity and kitsch, the following part is about eclectic structure and metafiction. Also in this part, 
intertextuality will be mentioned.

\section{Eclectic Structure and Metafiction}

Postmodernism has multi-layered in its structure, it is difficult to define eclectic objects, make up literature and art. It effects the periods from Ancient and to the present day but doesn't embrace items of the properties, these items are used in a new unity and lose their roots. The eclectic nature of postmodernism makes variations by using existences, hybridizes forms and types, changes formats, removes and re-establishes. Also the eclectic structure of "Fame" shows many affects from Ancient period and many movements. In the story "Rosalie Goes off to Die", the dialogue between Rosalie and taxi driver is remarkable: "The old riddle", he says with a sidelong glance at her face. "Oedipus and the Sphinx. In the morning, four; at midday, two; in the evening, three. So profound, dear lady." (op.cit.: 42)

Here the mentioned puzzle, is the puzzle asked to Oidipus on the way to Tebai by Sphinx. Sometimes, existential philosophy occurs (see: 94-95), sometimes also dreams filled with romantic effects (op.cit.: 22-23) and thoughts about reflection and reality evoking Plato (see: 53-56). At the same time, the attitudes of people through the world they live in baraqoe period combined with today's requirements:

"(...)the feeling of being a prisoner dishole part of the world was its own unique hell, you just knew instinctively you'd never get out. You'd have to be nutts to put yourself willingly in a situation like this" (op.cit.: 22).

Philosophical thoughts have dominant features in the work like the features of the periods. We have mentioned earlier, the ideas of Plato's world and the real world (which has been exhibited in reflection) as well as the sense of skepticism are presented: "If no one can prove me where I am, if I myself am not absolutely certain, where is the court that can adjudicate these things?" (op.cit.: 100-101).

However this skeptical understanding is different from that period but this skepticism is about technology benefits. With technology the understanding of being anywhere or talking nowhere, skepticism revealed in technological era. All these are blended by the events in today's technology era and combined under the structure of a new understanding (postmodern).

One of the most important elements of an eclectic structure in this Work is metafiction. It can be defined as fiction in fiction in fiction in a simple way. At the same time, by using metafictional elements, the postmodern authors point out a difference between reality and its linguistic representation. And also using metafictional elements point out the fictionality of fiction, involve a reader in a creation of meaning of the literary text.

In "Fame", metafictional elements are to be found too much. In particular the concept of fiction in fiction in fiction is clearly expressed by the author in the Work:

"We'r always in stories." (...) "stories within stories within stories. You never know where one ends and another begins! In truth, they all flow into one another. It's only in books that they'r clearly divided" (op.cit.: 117).

The author described the structure of the Work with these words. Other metafictional features reflected in the work like this: In the story named "In Danger", there is an author. The auther's name is Leo Richter and his character, loved by everybody, is Lara Gaspard. Leo and his girlfriend go different parts of the world to participate in a number of conferences and seminars and the questions to asked Leo are usually the same. The most striking question, "Well, what do you tell them?" "Bathtub." (see: 24, 25, 27, 84, 86).

Leo Richter isn't the only writer in the Work. In the story named "Replying to the Abbess", Miguel Auristos Blancos is a writer, who writes books in a variety of personal and spiritual growth. Persons in other stories read the works of Miguel. Because of technical error, Miguel called his friend but talked with Ebling who plays as his friend. Miguel said to him "I am going to swallow the hole container." And he answered "go right ahead"(op.cit.: 15). After this answer, Miguel puts an end to his life. Saying these words by Ebling, it is surprising that Miguel's books lying on the table. Maria Rubinstein, a character of fifth story, is a writer who writes dedective stories, she went to a tour of Central Asia instead of Leo Richter and can not be heard about her again. (see: 56-69).

As mentioned earlier, "Fame" is a novel composed of many stories and of course this is a metafictional indication. It tells another story in itself. And these stories break the novel from traditional molds like beginning, development and conclusion. At the end of the events, it is not certain where they begin and end, the reader can not take any result or doctrine from the story. That can be seen as a significant example of postmodern literary text feature as well.

Readers need to consider the following point: Who wrote the story named "Rosalie Goes off to Die", Leo Richter or 
Daniel Kehlmann? The answer is not obvious.

Another example of metafiction is a fictional character in communication with author. The fictional character Rosalie is in contact with the author, who creates and characterizes her, through the story, when she is unwilling to do in her life:

"Rosalie, it' not with in my power. I can't.

Of course you can! It's your story" (op.cit.: 34).

Metafictional elements of the Work are; fiction in fiction in fiction, a novel about a novel-author, a novel in a novel itself, a fictional character in a contact with the author, without beginning, development and conclusion.

In postmodern literature, metafiction has a close relationship with intertextuality. Intertextuality is a concept often associated with postmodernism, more particularly with that sphere of postmodernism where literature encounters critical theory (Kusnir, 2005:35). Julia Kristeva's definition of intertextuality is important: "Any text is constructed of a mosaic of quotations; any text is the absoption and transformation another" (Kristeva, 1980: 66). In Julia Kristeva's understanding, literary text is not only a product of a single author but of its relationship to other text and to the structures of language itself (Pokrivcak, 2006: 18). In the works intertextuality will occur in many different ways. Pokrivcak, classifies them as follows: "direct reference, allusion, quotation, echo, plagiarism, collage, mosaic, palimpsest and others" (op.cit.: 20).

"Fame" shows similar features with "New York Triology" by Paul Auster. The first story of "Fame", "Voices", thematizes confounding telephone numbers and reaching wrong person and then everything changes into a play. In the novel "City of Glass", a couple of evening Quinn called by a person he doesn't know. He says that he wants to talk a dedective named Paul Auster and in third call, Quinn introduces himself as Paul Auster and play begins like that. Intertextuality factors of "Fame" are parody and collage. Work, in general, as stated on the cover, established nine multistory as a novel. Although each story has been seen as different from each other, they are all in a close relationship with using collage. The elements of the collage such as different styles, characters, narrative voices can be understood only in their relation to chapters, styles, characters from other parts of the book. To D'haen's argument, postmodern collage evokes the effect of multiplicity rather than simultaeity (D'haen, 1991: 220). Postmodern collage is closely connected with fragmentation plurality and relativization. In the Work, characters, parts and story tellers are in contact with each other.

The striking spots in this collage are telephone and books. The telephone number of Ralf Tanner is accidentally given to Ebling, Ebling is bored of people who call Ralf, and so talks as if he is Ralf and causes to Miguel's death. Telecom chief, who gives wrong number to Ebling, sends his employees to a prensentation. Employee meets Leo Richter in this presentation, he is a fan of Leo especially his character Lara Gaspard. Lara Gaspard is Rosalie's nephew. Maria Rubenstein goes to a conference on behalf of Leo Richter and she is lost there. The wrong given phone number and behaviours of people unlike themselves let the events interlocking. The story Rosalie Goes off to Die shows feature of parody in this collage. Rosalie suffers from cancer and goes to euthanasia center in Switzerland (or sent by the author). Rosalie does not want to actually do it. She has various thoughts until coming to Switzerland. She wants to have her health again and become young. At this point, it is necessary to touch upon the work "Black Swan" (Die Betrogene) by Thomas Mann. In that Work Rosalie Tümmler fells in love a young man but indeed she is away from womanhood productivity, but this love brings her womanhood again. While she is thinking to have her youthness again, she is actually cancer and dies because of this illness. Parody is conspicuous to replace the head and the end in here. Young Rosalie disappears as a breeze, old Rosalie but feels young, dies because of cancer. Eclectic structure in here turned into a different structure from the perspective of the divine by taking canon with a new approach.

The key point of this work is the fact that the mistake of telecommunications company, because of the mistake, people's lifes confuse and everyone's true characters appear in a sense. Author's references to usage of technology especially computers and internet are noteworthy (Fame: 78, 79, 80). Except that the references to technology in the following words about the writing is remarkable:

"(...) In addion to which, I'm not really the kind of writer who uses real facts. Others like to be metuculous and naildown every single tiny detail, so that some shop that one of their characters is wandering past has the exact right name in the book. This sort of thing leaves me cold"(op.cit.: 33).

There is a criticism to authors who write everything in a reality atmosphere. There is a subtle message directed to a realist or naturalist authors. Again, with the words of the author, it is also possible to make a distinction between reality and fiction. 
"Fame" is a Work to exhibit postmodern characteristics founded on an eclectic building structure, enriched with metafiction and intertextuality. It also benefits from identity and kitsch elements by using pluralism. Aspect of pluralism of the Work can provide itemized as follows:

- First need to be said, the novel composes of stories and it is the most prominent feature of pluralism. Technique of intertextuality and metafiction plays an important role here.

- Characters in the Work don't show a single personality trait, they are usually divided into two personalities revealed pluralistic.

- As a matter of eclectic form, it is used some literary currents and thoughts, and not influenced only one understanding or current.

- With the tecnique of collage breaks the linearity of narration, enables the stylisitic and generic hybridity and offers a multiple, pluralistic vision of the worlds.

\section{Conclusion}

In this study we aimed to reveal postmodern features by means of Daniel Kehlmann's Work "Fame". Primarily the result we reached is about indefinability of the term. Postmodernism has been shaped by uncertainty, does not constitute elements of unity like time, space and subject. Because of not being confined in a spesific timeframe, we can say that it is a literary form rather than a literary current. As mentioned at the beginning of the study, we tried to identify such cases like, complexity of plot and identity, pluralism, uncertainty, eclectic structure, collage, metafiction, intertextuality instead of making description and all of these features have been revealed by examples from the Work. These features prove to constitute a cohesive structure all the elements of postmodern literature. In light of these, if comparative analyse is made between this Work and other Works belonging to postmodern, it can be said that Fame has postmodern structure.

\section{References}

Aslışen, Mehmet (2006). Postmodern Süreçte Kitsch Olgusu. Masterthese. İzmir: Dokuz Eylül Üniversitesi.

D'haen, Theo (1991). "Postmodernism in American Fiction and Art". Approaching Postmodernism. (Eds. Douwe Fokkema, Hans Bertens). Amsterdam- Philadelphia: John Benjamins, 221-232.

Gelfert, Hans-Dieter (2010). Was ist gute Literatur? Wie man gute Bücher von schlechten unterscheidet. 3. Auflage. München: C.H. Beck Verlag.

Harbers, Henk (2000). Postmoderne Literatur in Deutscher Sprache: Eine Ästhetik des Widerstandes?. Amsterdam-Atlanta: GA Rodopi B.V.

Hassan, Ihab (1993). "Tpward a Concept of Postmodernism". Postmodernism: A Reader (Ed. Thomas Docherty). New York, London, Toronto, Sydney, Tokyo, Singapore: Harvester Wheatsheaf, 146-156.

KehImann, Daniel (2010). Fame, A Novel in Nine Episodes (Translated by Carol Brown Janeway). Newyork: Pantheon Books (e-book).

Kristeva, Julia (1980). Desire in Language: A Semiotic Approach to Literature and Art. New York: Columbia University Press.

Kusnir, Jaroslav (2005). American Postmodern Fiction. Modernism- Postmodernism, Popular Culture, and Metafiction. Stuttgart: Ibidem Verglag.

Pokrivcak, Anton (2006). "Literary History". Pokrivcak Anton, Pokrivcakova Silvia. Understanding Literature. Brno: MSD, 21-29.

Türk, Taner (2012). Paul Auster ve Metin Kaçan'ın Eserlerinde Postmodern Öğelerin Karşılaştırmalı Analizi. Masterthese. Konya: Selçuk Universitesi Sosyal Bilimler Enstitüsü.

http://www.frustfrei-lernen.de/deutsch/postmoderne-deutsche-literatur-und-epochen.html 01.06 .2013 (online).

http://www.berlinerliteraturkritik.de/fileadmin/download/BLK2009_01_onlpdf.pdf 15.06.2013 (online). 